\title{
MENINGKATKAN KEMAMPUAN MEMBACA SISWA MELALUI TEKHNIK PERMAINAN BAHASA MELENGKAPI CERITA
}

\author{
Nur Fadilah \\ Institut Agama Islam Syarifuddin Lumajang, Indonesia \\ Email: fataalways58@gmail.com
}

\begin{abstract}
Abstrak
Salah satu faktor merosotnya kemampuan siswa disebabkan karena kurangnya kreatifitas guru dalam proses belajar mengajar, apalagi pada mata pelajaran Bahasa Indonesia yang berisi teks materi sehingga cenderung membosankan jika hanya disampaikan melalui ceramah.

Metode (field research) dengan pendekatan kualitatif deskriptif yang digunakan dalam penelitian ini, sebab peneliti terjun langsung pada lokasi penelitian. Peneliti menggunakan wawancara, observasi dll dalam pengumpulan data.

Penelitian ini menunjukan bahwa ketika guru menggunakan tekhnik permainan bahasa melengkapi cerita pada siswa, akhirnya guru mampu meningkatkan kemampuan siswa kelas II Madrasah Ibtidaiyah Nurul Islam Uranggantung, bahkan dengan adanya menggunakan tekhnik permainan bahasa melengkapi cerita, siswa mampu menjuarai lomba membaca puisi tingkat kecamatan.
\end{abstract}

Kata kunci: Permainan Bahasa, Melengkapi Cerita.

\section{Pendahuluan}

Membaca permulaan merupakan tahapan proses belajar membaca bagi siswa Madrasah Ibtidaiyah kelas awal. Siswa belajar untuk memperoleh kemampuan dan menguasai teknik-teknik membaca dan menangkap isi bacaan dengan baik. Oleh karena itu, guru perlu merancang pembelajaran membaca dengan baik sehingga mampu menumbuhkan kebiasan membaca sebagai suatu yang menyenangkan. Suasana belajar harus dapat diciptakan melalui kegiatan permainan bahasa dalam pembelajaran membaca. Hal itu sesuai dengan karakteristik anak yang masih senang bermain. Permainan memiliki peran penting dalam perkembangan kognitif dan sosial anak. Membaca merupakan 
salah satu keterampilan berbahasa yang diajarkan dalam mata pelajaran bahasa Indonesia di Sekolah Dasar1.

Keterampilan membaca sebagai salah satu keterampilan berbahasa tulis yang bersifat reseptif perlu dimiliki siswa Sekolah Dasar/MI agar mampu berkomunikasi secara tertulis ${ }^{2}$. Oleh karena itu, peranan pengajaran Bahasa Indonesia khususnya pengajaran membaca di MI menjadi sangat penting. Pengajaran Bahasa Indonesia di MI yang bertumpu pada kemampuan dasar membaca dan menulis juga perlu diarahkan pada tercapainya kemahirwacanaan. Keterampilan membaca dan menulis, khususnya keterampilan membaca harus segera dikuasai oleh para siswa di MI karena keterampilan ini secara langsung berkaitan dengan seluruh proses belajar siswa di MI. Keberhasilan belajar siswa dalam mengikuti proses kegiatan belajar-mengajar di sekolah sangat ditentukan oleh penguasaan kemampuan membaca mereka.

Siswa yang tidak mampu membaca dengan baik akan mengalami kesulitan dalam mengikuti kegiatan pembelajaran untuk semua mata pelajaran. Siswa akan mengalami kesulitan dalam menangkap dan memahami informasi yang disajikan dalam berbagai buku pelajaran, buku-buku bahan penunjang dan sumber-sumber belajar tertulis yang lain. Akibatnya, kemajuan belajarnya juga lamban jika dibandingkan dengan teman-temannya yang tidak mengalami kesulitan dalam membaca. Tujuan membaca permulaan di kelas rendah adalah agar siswa dapat membaca kata-kata dan kalimat sederhana dengan lancar dan tepat. ${ }^{3}$ Kelancaran dan ketepatan anak membaca pada tahap belajar membaca permulaan dipengaruhi oleh keaktifan dan kreativitas guru yang mengajar di kelas rendah. Dengan kata lain, guru memegang peranan yang strategis dalam meningkatkan keterampilan membaca

\footnotetext{
${ }^{1}$ Muchlisoh, Materi Pokok Bahasa Indonesia, ( Jakarta:Depdikbud,1992), 119.

${ }^{2}$ Henry Guntur Tarigan, Membaca Sebagai Suatu Keterampilan Berbahasa, (Bandung:CV Angkasa,2015),7.

${ }^{3}$ Depdikbud, Dikti, Pengjaran Membaca ( Jakarta: Depdikbud, 1992).
} 
siswa. Peranan strategis tersebut menyangkut peran guru sebagai fasilitator, motivator, sumber belajar, dan organisator dalam proses pembelajaran. Guru yang berkompetensi tinggi akan sanggup menyelenggarakan tugas untuk mencerdaskan bangsa, mengembangkan pribadi manusia Indonesia seutuhnya dan membentuk ilmuwan dan tenaga ahli. Pelaksanaan pembelajaran Bahasa Indonesia di MI ialah guru terlalu banyak menyuapi, tetapi kurang menyuruh siswa aktif membaca, menyimak, menulis dan berbicara ${ }^{4 \prime}$.

Untuk mengoptimalkan pembelajaran membaca permulaan di MI salah satu alternatif yang dapat dilakukan ialah melalui permainan bahasa. Mmaksud dengan "Bermain dalam konteks pembelajaran tidak sekedar bermain-main. Namun, bermain memberikan kesempatan pada anak untuk mengembangkan kemampuan emosional, fisik, sosial dan nalar siswa". Melalui interkasinya dengan permainan, seorang anak belajar meningkatkan toleransi mereka terhadap kondisi yang secara potensial dapat menimbulkan frustrasi. Kegagalan membuat rangkaian sejumlah obyek atau mengkonstruksi suatu bentuk tertentu dapat menyebabkan anak mengalamai frustrasi. Dengan mendampingi anak pada saat bermain, pendidik dapat melatih anak untuk belajar bersabar, mengendalikan diri dan tidak cepat putus asa dalam mengkonstruksi sesuatu. Bimbingan yang baik bagi anak mengarahkan anak untuk dapat mengendalikan dirinya kelak di kemudian hari untuk tidak cepat frustrasi dalam menghadapi permasalahan kelak di kemudian hari.

Secara fisik, bermain memberikan peluang bagi anak untuk mengembangkan kemampuan motoriknya. Permaian seperti dalam olahraga mengembangkan kelenturan, kekuatan serta ketahanan otot pada anak. Permaian dengan kata-kata (mengucapkan kata-kata) merupakan suatu kegiatan melatih otot organ bicara sehingga kelak pengucapan kata-kata menjadi lebih baik. Diaz, A. mengemukakan pula

${ }^{4}$ J.S Badudu, Pengajaran Bahasa Indonesia, ( Yogyakata: Kanasius, 1993), 131. 
bahwa dalam bermain, anak juga belajar berinteraksi secara sosial, berlatih untuk saling berbagi dengan orang lain, menignkatkan tolerasi sosial, dan belajar berperan aktif untuk memberikan kontribusi sosial bagi kelompoknya.

Melalui bermain, anak juga berkesempatan untuk mengembangkan kemampuan nalarnya, karena melalui permainan serta alat-alat permainan anak-anak belajar mengerti dan memahami suatu gejala tertentu. Kegiatan ini sendiri merupakan suatu proses dinamis di mana seorang anak memperoleh informasi dan pengetahuan yang kelak dijadikan landasar dasar pengetahuannya dalam proses belajar berikutnya di kemudian hari.

\section{Pembahasan}

\section{Perencanaan Tekhnik Permainan Bahasa Melengkapi Cerita}

Berdasarkan hasil observasi, tekhnik permainan bahasa melengkapi cerita diawali dengan pembuatan RPP yang dilakukan oleh guru wali kls 11 disekolah setelah pembelajaran berakhir, sebagai persiapan untuk prmbrlajaran yang akan datang. tekhnik permainan bahasa melengkapi cerita ini sudah agak lama saya terapkan, karna memang pada usia siswa kls 2 ini yang memang masih senang dengan bermain maka dari itu saya lakukan pembelajaran sambil bermain, karna dengan permainan bahasa ini tahap pembelajaran lebih aktif dan membuat siswa lebih senang dalam mengikuti pembelajaran. Salah satu cara atau tahap dalam penerapan tekhnik permainan bahasa melengkapi cerita ini adalah persiapan awal, yaitu dengan membuat Rpp, pembuatan RPP ini dilakukan atau dibuat di sekolah setelah proses pmbelajaran berakhir. Pembuatan RPP ini sebagai acuan guru di dalam kelas, sehingga tekhnik permainan bahasa melengkapi cerita ini berjalan dengan efektif. ${ }^{5}$

Selain rencana kegiatan pembelajaran yang harus disusun, metode yang akan digunakan pun juga harus direncanakan, perencanaan metode

${ }^{5}$ Desi, Wawancara, Madrasah Ibtidaiyah Nurul Islam Uranggantung, 21 Maret 2017 
ini dilakukan agar guru mengetahui alur proses pembelajarann dan tidak kehilanga arah pembelajaran. Metode pembelajaran itu akan lebih efektif dan menyenangkan jika metode itu disusun dan disesuaikan dengan kondisi dan keadaan siswa. Jadi tidak semerta-merta melaksanakan pembelajaran tanpa metode yang nantinya hanya membuat siswa jenuh dan tidak semangat, bahkan bisa jadi siswa minta segera istirahat atau pulang.

Pembelajaran bahasa Indonesia dengan menggunakan tekhnik permainan bahasa melengkapi cerita benar benar dilakukan dengan professional, karna guru sudah menyiapkan peran serta tanggung jawab secara jelas serta adil. Seperti yang telah dilakukan oleh Ibu Desi membentuk kelompok permainan secara acak agar merata dan tidak terjadi pemilihan yang tidak sesuai. ${ }^{6}$ Disamping itu selain merencanakan dan menyiapkan perangkat pembelajaran media yang diperlukan dalam metode itu juga harus disiapkan dan dirancan sebelum proses pembelajaran dimulai. Selain menyiapkan perangkat pembelajaran saya juga perlu menyiapkan alat-alat yang dibutuhkan untuk membuat media pembelajaran yang akan dipakai, dalam permainan bahasa melengkapi cerita ini membutuhkan beberapa peralatan seperti, Kertas lipat untuk membuat kartu kata, gunting, spidol, krtas karton dan double tap untuk menempel.

\section{Pelaksanaan Tekhnik Permainan Bahasa Melengkapi Cerita}

Pelaksanaan pembelajaran meningkatkan kemampuan membaca dengan menggunakan teknik permainan bahasa melengkapi cerita dapat memberikan suatu situasi belajar yang santai dan menyenangkan. Siswa dengan aktif dilibatkan dan dituntut untuk memberikan tanggapan dan keputusan. Dalam memainkan suatu permainan, siswa dapat melihat sejumlah kata-kata berkali-kali namun tidak dengan cara yang membosankan. Pada pelaksanaan pembelajaran menggunakan teknik

${ }^{6}$ Observasi, Madrasah Ibtidaiyah Nurul Islam Uranggantung, 27 maret 2017. 
permainan bahasa melengkapi cerita, siswa diarahkan untuk dapat mengorganisir daya nalarnya tentang suatu cerita atau alur yang tepat.hal tersebut diharapkan dapat menambah pemahaman siswa tentang membaca, karena siswa melihat sejumlah kata berkali-kali untuk melengkapi teks cerita yang kata-katanya telah ditanggalkan dengan katakata yang tepat.

Kegiatan pembelajaran Pembelajaran Meningkatkan Kemampuan Membaca Dengan Menggunakan Teknik Permainan Bahasa Melengkapi Cerita dapat dari gambaran pembelajaran berikut :

1. Siswa dibagi menjadi beberapa kelompok.

2. Siswa menyimak cerita pendek yang dibacakan oleh guru.

3. Guru bersama siswa melakukan tanya jawab cerita pendek yang telah dibaca.

4. Guru menyiapkan alat pembelajaran yaitu teks cerita pendek yang belum lengkap yang ditulis dalam karton dengan jumlah sesuai dengan kelompok belajar dan menempelkannya di depan kelas.

5. Guru menjelaskan cara permainan melengkapi cerita.

6. Secara berkelompok siswa melakukan permaianan bahasa yaitu melengkapi cerita dengan kata-kata yang tepat dengan kartu kata yang telah disediakan guru.

7. Pengumuman hasil permainan, kelompok yang berhasil melengkapi cerita dengan waktu cepat mendapatkan reward dan kelompok yang menyelesaikan dengan waktu yang lama mendapatkan sanksi.

8. Setelah melakukan permaianan bahasa melengkapi cerita, siswa membaca teks cerita pendek tersebut dengan lafal dan intonasi yang tepat.

Selain Tahap persiapan, langkah-langkah penggunaan tekhnik permainan bahasa melengkapi cerita di MI Nurul Islam Uranggantung dilakukan dengan tahap inti atau pelaksanaan. Selain tahap persiapan, 
pelaksanaan penggunaan tekhnik permainan bahasa melengkapi cerita di kls 11 MI Nurul Islam Uranggantung juga dilakukan dengan tahap inti yaitu kegiatan pembelajaran berlangsung, maka strategi pembelajaran dilaksanakan dengan cara menjelaskan peraturan permainan tekhnik permainan bahasa melengkapi cerita ini dan bentuk-bentuk latihan yang akan dilakukan, lalu memulai latihan dngan hal hal yang sederhana dulu sambil memeberikan motivasi agar siswa terus melakukan latihan secara berkesinambungan. Penjelasan diatas menunjukkan bahwa pelaksanaan penggunaan tekhnik permainan bahasa melengkapi cerita yang dilakukan oleh guru Kls 11 melalui tahap awal yaitu persiapan sebelum mengajar terlebiih dahulu, lalu tahap inti yaitu ketika pembelajaran berlangsung.

Sebagai salah satu usaha saya dalam meningkatkan kualitas pendidikan yang sedang saya kelola saat ini adalah dengan cara saya selalu menanyakan kepada segenap dewan guru disini untuk selalu berusaha menggunakan strategi pembelajaran yang sesuai dengan tujuan untuk menghasilkan suatu pmbelajaran sbagaimana yang diharapkan, selain melakukan tahap persiapan dalam mengajar, kami juga berupaya menggunakan berbagai metode pembelajaran termasuk Permainan Bahasa Melengkapi Cerita dengan cara menyajikan bahan pelajaran dengan jalan melatih siswa agar menguasai pembelajaran dengan cepat serta memeberikan latihan dengan hal-hal yang sederhana dulu. Setelah melakukan laihan dengan hal-hal yang sederhana kemuadian dilanjutkan dengan penerapan teknik permainan Bahasa Melengkapi Cerita. ${ }^{7}$

Berdasarkan Observasi yang dilakukan oleh peneliti bahwa sistem pembelajar Tekhnik Permainan Bhasa Melengkapi Cerita yang diterapkan pada kls 11 MI Nurul Islam Uranggantung Lumajang dijalankan dalam bentuk sebagai berikut:

1. Siswa dibagi menjadi beberapa kelompok.

2. Guru menjelaskan cara permainan melengkapi cerita.

${ }^{7}$ Sa'in, Wawancara, Madrasah Ibtidaiyah Nurul Islam Uranggantung, 23 Maret 2017. 
Sebelum pembelajaran dilaksanakan dengan menggunakan tekhnik permainan bahasa melengkapi cerita guru menjelaskan terlebih dahulu peraturan dalam permainan ini, siswa menyimak apa yang dijelaskan oleh guru, kemudian guru membagi siswa menjadi beberapa kelompok, sedangkan siswa menyimak cerita pendek yang dibacakan oleh guru. Selanjutnya guru menyiapkan alat alat yang akan digunakan dalam permainan ini seperti kertas karton yang sudah ditulisi teks cerita pendek yang belum lengkap, dan beberapa kertas lipat yang sudah digunting dan ditulisi macam-macam kata unuk digunakan sebagai kartu kata sebagai pelengkap teks cerita pendek yang belum lengkap. Kemudian guru menempelkan kertas karton yang ditulisi teks cerita pendek yang belum lengkap di dinding dan papan tulis. Untuk selanjutnya siswa dengan kelompoknya masing-masing mulai permainan bahasa melengkapi cerita ini, dengan cara yang berbeda dari masing-masing kelompok seperti yang dilakukan oleh kelompok, salah satu anggota kelompok membacakan teks yang ditulis di dalam kertas karton dan sebagian anggota lain mencari sebuah kata yang tepat untuk melengkapi beberapa kalimat tersebut, dan ada juga yang menempel sebuah kata yang sudah ditemukan dan pantas untuk melengkapi kalimat-kalimat yang kurang sehingga menjadi sebuah cerita yang lengkap dan runtut.

Setelah melakukan permainan tersebut siswa kembali ketempat masing-masing dan guru mengeumumkan sipa kelompok yangberhasil melengkapi cerita dengan waktu cepat dan benar akan mendapatkan reward sedangkan untuk siswa yang menyelesaikan paling akhir guru terus memotivasi supaya rajin belajar membaca karna ketika mereka tidak lancar dalam membaca mereka pun akan sulit untuk menyelesaikan permainan itu, jadi siswa dianjurkan untuk selalu belajar membaca agar ketikan permainan ini dilakukan kembali dapat menyelesaikan permainan ini dengan cepat dan baik dan akan mendapat hadiah dari guru. 
Selain penerapan tekhnik permainan bahasa melengkapi cerita maka diadakan pula tahap Evaluasi pada siswa Kls 11 MI Nurul Islam Uranggantung setelah melakukan Teknik Permainan Bahasa Melengkapi Cerita tersebut. Dalam hal ini evaluasi siwa mencakup pembuatan tugas evaluasi dan merencanakan metode evaluasi, guru harus membuat soalsoal evaluasi yang akan diberikan kepada siswa, baik dengan cara membaca, menghafal dan lain-lain.

Peningkatan kemampuan membaca siswa melalui teknik permainan bahasa melengkapi cerita di Kelas II MI Nurul Islam Uranggantung. Hasil dari pembelajaran meningkatkan kemampuan membaca dengan menggunakan teknik permainan bahasa melengkapi cerita adalah berupa peningkatan kemampuan siswa dalam membaca. Setelah siswa melaksanakan pembelajaran membaca dengan menggunakan teknik permainan bahasa melengkapi cerita ini diharapkan siswa dapat membaca dengan fasih serta menggunakan lafal dan intonasi yang tepat.

Standar diketahuinya peningkatan kemampuan pada siswa kelas II Sekolah Dasar. Cara untuk mengetahui adanya peningkatan kemampuan anak dalam membaca dapat diketahui dengan menilai; Kefasihan dalam membaca lancar, kurang lancar, atau tidak lancar. Pelafalan dalam membaca tepat, kurang tepat atau tidak tepat. Intonasi dalam membaca tepat, kurang tepat atau tidak tepat.

Pemilihan aspek-aspek tersebut berdasarkan pada tuntutan kurikulum yang tercantum dalam kompetensi dasar yang harus dikuasai oleh siswa setelah pembelajaran berlangsung. Pada kompetensi dasar tercantum bahwa siswa harus dapat memebaca nyaring dengan lafal dan intonasi yang tepat. Penjelasan diatas menunjukkan bahawa hasil atau peningkatan dari penggunaan tekhnik permainan bahasa melengkapi cerita dapat dilihat dari meningkatnya semangat belajar siswa dalam membaca, dan ketika siswa sudah semangat dalam belajar membaca maka dengan mudah kemampuan membaca siswa juga akan meningkat. 
Hal ini terbukti pada salah satu siswa kls 11 yang awalnya kemampuan membacanya sangat rendah sekarang sudah semakin meningkat saat membaca teks cerita "Sapi dan Kerbau Bertukar Baju" pada pelajaran 9 tentang Kebutuhanku. Hal ini disebabkan karna adanya tekhnik permainan bahasa melengkapi cerita ini mendorong siswa untuk semakin giat dalam belajar membaca. Karna siswa bisa menyelesaikan permainan tersebut dengan baik dan memenangkan permainan itu ketika siswa itu bisa membaca dengan lancar.

Selain itu juga dibuktikan oleh salah satu siswi yang bernama indi pada saat membacakan teks puisi tentang "GURUKU" pada pelajaran 10 tentang budi pekerti, dia membacakan puisi nya dengan sangat baik dia juga memakai pelafan dan intonasi yang tepat. Jadi sudah terbukti bahwa tekhnik permainan bahasa melengkapi cerita ini dapat Meningkatkan kemampuan membaca siswa yang awalnya masih kurang baik menjadi semakin baik dan meningkat.

Menurut Ibu Menik, hasil dari penggunaan tekhnik permainan bahasa melengakapi cerita ini bisa dilihat dari semangat belajar membaca siswa kls ll, saya sendiripun sering melihat siswa kls 11 yang biasanya waktu istirahat sekarang malah duduk di dalam atau diluar kls sambil membaca buku, meski terkadang hanya buku cerita yang dibaca, jadi Tekhnik Permainan Bahasa Melengkapi Cerita itu dapat menanamkan pada siswa kebiasaan membaca, sehingga dengan mudah dapat meningkatkan kemampuan membaca siswa. ${ }^{8}$

Penjelasan di atas menunjukkan bahawa dengan menggunan tekhnik permianan bahasa melengkapi cerita dalam waktu relatif singkat, siswa mudah memperoleh penguasaan dan ketrampilan yang diharapkan. Setiap sudah melakukan pembelajaran, guru selalu memberikan tugas atau PR membaca, karna itu saya jadi sering membaca dan karana sering membca maka saya semakin lancar dalam membaca. Berdasarkan

${ }^{8}$ Menik, Wawancara, Madrasah Ibtidaiyah Nurul Islam Uranggantung, 23 Maret 2017. 
beberapa pendapat di atas dapat di simpulkan bahwa penggunaan tekhnik permainan bahasa melengkapi cerita pada kls 11 MI Nurul Islam Uranggantung ternyata dapat meningkatkan kemampuan membaca siswa kls 11 dilihat dari seringnya siswa kls 11 belajar membaca sehingga dapa meningkatkan kemampuan membaca siswa. ${ }^{9}$

Prestasi belajar merupakan hasil belajar yang telah dicapai menurut kemampuan yang dimiliki dan ditandai dengan perkembangan serta perubahan tingkah laku pada diri seseorang dengan waktu tertentu. Prestasi belajar ini dapat diyatakan dalam bentuk nilai tes atau ujian. Hasil yang didapat dalam hal ini adalah adanya prestasi yang tinggi yang ditandai dengan adanya hasil tes atau hasil belajar siswa dari sebelumnya kurang maksimal dan sekrang lebih memuaskan. ${ }^{10}$ Penggunaan tekhnik permainan bahasa melengkapi cerita pada pembelajaran Bahasa Indonesia dapa menanamkan pada diri siswa akan kebiasaan belajar yang rutin sehingga tumbuh semangat belajar yang tinggi dalam pembelajaran membaca dan melalui belajar membaca yang rutin akan memperoleh hasil yang memuaskan. ${ }^{11}$ Dari hasil wawancara diatas dapat diketahui bahwa hasil yang didapat adalah adanya prestasi yang tinggi yang ditandai dengan adanya peningkatan hasil tes siswa yang lebih baik dari sebelumnya, tapi ada juga yang kurang semangat dalam belajar karna kurangnya dukungan orang tua maupun lingkungan sekitar.

Penerapan tekhnik permainan bahasa melengkapi cerita ditunjukkan dengan adanya prestasi belajar yang tinggi ditandai dengan adanya peningkatan hasil tes membaca siawa yang lebih baik dari sebelumnya. Namun ada juga yang hasilnya masih kurang maksimal, dalam hal ini dalah siswa yang kurang dapat perhatian atau dukungan dari orang tuanya di rumah ataupun lingkungan sekitar dikarenakan orang tua kurang memahami pening nya belajar. Selain dibuktikan dengan hasil tes

\footnotetext{
${ }^{9}$ Menik, Wawancara, Madrasah Ibtidaiyah Nurul Islam Uranggantung, 23 Maret 2017.

${ }^{10}$ Desi, Wawancara, Madrasah Ibtidaiyah Nurul Islam Uranggantung, 23 Maret 2017.

${ }^{11}$ Menik, Wawancara, Madrasah Ibtidaiyah Nurul Islam Uranggantung, 30 Maret 2017.
} 
yang tinggi prestasi belajar membaca siswa kls 11 MI Nurul Islam Uranggantung juga dibuktikan dengan meraihnya juara dua lomba puisi tingkat kecamatan oleh ananda Iza Nazilatur Rohmah tahun 2017. Karena semakin meningkatnya kemauan siswa tersebut dalam belajar membaca sehingga pada akhirnya siswa tersebut terpilih menjadi perwakilan dari MI Nurul Islam Sukodono untuk mengikuti ajang perlombaan membaca puisi tingkat kecamatan, dan siswa tersebut pun mendapatkan hasil yang memuaskan yaitu meraih juara kedua dalam perlombaan itu. ${ }^{12}$

\section{Penutup}

Rencana pelaksanaan pembelajaran dalam meningkatkan kemampuan membaca siswa melalui teknik permainan bahasa melengkapi cerita di Kelas II MI Nurul Islam Uranggantung. tekhnik permainan bahasa melengkapi cerita diawali dengan pembuatan RPP yang dilakukan oleh guru wali kls 11 disekolah setelah pembelajaran berakhir, sebagai persiapan untuk pembrlajaran yang akan datang.

Proses Pelaksanaan Pembelajaran Tekhnik Permainan Bahasa Melengkapi Cerita Dalam Meningkatkan Kemampuan Membaca Siswa Melalui Tekhnik Permainan Bahasa Melengkapi Cerita di Kls 11 MI Nurul Islam Uranggantung. Menggunakan langkah penggunaan Tekhnik Permainan Bahasa Melengkapi Cerita di MI Nurul Islam Uranggantung dilakukan dengan tahap inti atau pelaksanaan. Sehingga bisa meningkatkan kemampuan membaca siswa pada mata pelajaran Bahasa Indonesia melalui Tekhnik Permainan Bahasa Melengkapi Cerita.

\section{Daftar Pustaka}

Badudu J.S, 1993, Pengajaran Bahasa Indonesia, Yogyakata: Kanasius.

Desi, 2017, Wawancara, Madrasah Ibtidaiyah Nurul Islam Uranggantung. Wawancara, Madrasah Ibtidaiyah Nurul Islam Uranggantung. , Wawancara, Madrasah Ibtidaiyah Nurul Islam Uranggantung.

\footnotetext{
${ }_{12}$ Desi, Wawancara, Madrasah Ibtidaiyah Nurul Islam Uranggantung, 30 Maret 2017.
} 
Dikti, 1992, Pengjaran Membaca, Jakarta: Depdikbud.

Menik, 2017, Wawancara, Madrasah Ibtidaiyah Nurul Islam Uranggantung.

Wawancara, Madrasah Ibtidaiyah Nurul Islam Uranggantung.

Muchlisoh, Materi Pokok Bahasa Indonesia, Jakarta: Depdikbud.

Observasi, 2017, Madrasah Ibtidaiyah Nurul Islam Uranggantung.

Sa'in, 2017, Wawancara, Madrasah Ibtidaiyah Nurul Islam Uranggantung.

Tarigan Henry Guntur, 2015, Membaca Sebagai Suatu Keterampilan Berbahasa, Bandung: CV Angkasa. 
Nur Fadilah

60 | Bidayatuna, Vol. 01 No. 01 April 2018 